REV. TOMASZ BAĆ

\title{
The Renewal of the Ambrosian and the Hispano-Mozarabic Liturgy after the Second Vatican Council
}

The renewal of the liturgy and its general reform made after the Second Vatican Council generally concerns the Roman Rite, which all instructions of the Constitution on the Sacred Liturgy Sacrosanctum Concilium refer to. The conciliar fathers were well aware of the fact that there is a need for renewing other rites and traditions existing in the Church. ${ }^{1}$ In the introduction to the first conciliar constitution it was stated that: "In faithful obedience to tradition, the sacred Council declares that holy Mother Church holds all lawfully acknowledged rites to be of equal right and dignity; that she wishes to preserve them in the future and to foster them in every way. The Council also desires that, where necessary, the rites be revised carefully in the light of sound tradition, and that they be given new vigor to meet the circumstances and needs of modern times" (Constitution Sacrosanctum Concilium, 4).

In the Latin Church, from among many local rites which, throughout centuries and alongside the Roman Rite, served as evidence of the richness of the Christian liturgy, tradition and culture, only two rites were

\footnotetext{
${ }^{1}$ In the context of liturgy renewal after the Second Vatican Council the terms "rite" and "liturgy" may be considered to be synonyms, although their meaning is not, in fact, identical; cf. A. M. Triacca, La Liturgia ambrosiana, [in:] La Liturgia: panorama storico generale, Genova 2002, p. 88 (Anàmnesis, 2).
} 
preserved: the Ambrosian Rite, continuously practised in the greater part of the Archdiocese of Milan, Italy, and some parishes of adjacent dioceses and the Hispano-Mozarabic Rite, which is the everyday liturgy in one of the chapels in the Primate Cathedral in Toledo. These are the two "lawfully acknowledged rites" that article 4 of the Constitution on the Sacred Liturgy refers to. ${ }^{2}$

The sheer fact that in the Western Christianity traditions other than the Roman one were preserved is of great importance not only for the local churches in Milan and Toledo, but also for the Universal Church as a whole. That is why getting acquainted with the history and the fruits of the process of their renewal lets us perceive the $20^{\text {th }}$ century liturgical reform in the Catholic Church in a broader light.

\section{The Ambrosian and the Mozarabic Liturgy on the Threshold of the Conciliar Renewal}

Despite the common foundation in the conciliar constitution, the renewal of the two rites was separate and had different dynamics, methodology and range. However, the most crucial difference between the two rites lies in the origin of the process of renewal. The Ambrosian Rite is the rite of the particular Church, which formed throughout centuries and was the basis of the Christian culture connected with Milan - one of the most important centres of Western Christianity. The Ambrosian Liturgy is rooted in the times of St. Ambrose, although the beginnings of its codification are connected with the liturgical reforms in the Latin Church in the Carolingian period, and its extremely dynamic development was never endangered. ${ }^{3}$ The Church in Milan has always had her own liturgical tradition, more or less respected by the Roman Church, and great pastors associated with it such as Carlo Borromeo ( $\uparrow 1584)$, Andrea

${ }^{2}$ Cf. V. A. Lenti, Liturgical Reform and the Ambrosian and Mozarabic Rites, "Worship" 68 (1994), p. 418-419.

${ }^{3}$ Cf. C. Krakowiak, Ryt i liturgia ambrozjańska, „Vox Patrum” 34-35 (1998), p. 156. 
Carlo Ferrari († 1921) and Alfredo Ildefonso Schuster († 1954) not only guaranteed the preservation of this tradition, but also the development and enormous influence on the Christian identity of the faithful. What is more, the Christianity in Milan has always been integrally connected with the Ambrosian Rite. Many centuries of tradition and strong attachment of the clergy and the faithful form the basis of the strong drive to discover and renew ambrosianum mysterium, which means the most typical elements of Ambrosian culture, liturgy and spirituality. Because of that, right after the Second Vatican Council, the Church in Milan was faced with the necessity of rethinking her own liturgical identity. ${ }^{4}$

Due to the turbulent history of the Mozarabic Liturgy, its situation before Vaticanum II was completely different. The beginnings of Christianity on the Iberian Peninsula can be traced to the Apostolic times, and the Church in Spain flourished in the $6^{\text {th }}$ and the $7^{\text {th }}$ centuries. That is when her own liturgy reached its peak in the pastoral and theological dimensions. ${ }^{5}$ The great Fathers of the Visigothic period (from 589 to 711): Leander and Isidore of Seville and Eugenius, Ildefonsus and Julian of Toledo played an important part in the process of formation of the Spanish liturgy. The Arab seizure of the greater part of the Iberian Peninsula starting from $711 \mathrm{AD}$, as well as internal theological disputes in the Spanish Church, made the papacy more suspicious about the liturgy, which was already at that time referred to as Mozarabic, and was significantly different from the Roman one. The pressure from Rome and the growing influence of the Benedictines from Cluny resulted in the decision of the Council of Burgos in 1080 to substitute the traditional Spanish liturgy with the Roman one. It was part of the policy of Pope Gregory VII whose activities consistently aimed at building the unity of the Church based on the papal liturgy. Despite some problems, the decisions of the Council of Burgos were introduced almost in the whole, gradually reclaimed from the Arabs, kingdom of Alfonso VI. The only place where the celebration of the old Spanish rite remained unchanged was Toledo, conquered by

\footnotetext{
${ }^{4}$ Cf. C. Alzati, Il Lezionario della Chiesa ambrosiana: la tradizione liturgica e il rinnovato „ordo lectionum,” Città del Vaticano-Milano 2009, p. 65.

${ }^{5}$ Cf. J. Pinell, La Liturgia ispanica, [in:] La Liturgia: panorama..., op. cit., p. 73
} 
Alfonso VI in 1085. It was the place where, despite the malevolence of the bishop, the monk from Cluny - Bernard de Sedirac, in six parishes the faithful were able to take part in the liturgy so dear to them. ${ }^{6}$ The next few centuries were the period of the fall of the Mozarabic liturgy. At the turn of the $15^{\text {th }}$ and the $16^{\text {th }}$ centuries Cardinal Francisco Ximénes de Cisneros decided to renew and publish Mozarabic liturgical books on the basis of the manuscripts he was familiar with, that came from one euchological tradition. In this way Missale mixtum secundum regulam beati Isidori dictum mozárabe (1500) and Breviarium secundum regulam beati Isidori $(1502)^{7}$ were created. Cardinal Cisneros chose the Corpus Christi chapel in the Primate Cathedral of Toledo as a place for the daily celebration of the Holy Mass and the breviary offices in accordance with the renewed Mozarabic liturgical books. ${ }^{8}$ The task of taking care of the Mozarabic liturgy was given to the group of specially designated Chapter of canon priests. The following reform of the liturgical books, comprising in their republishing, was made by Cardinal Francisco de Lorenzana, who published Breviarium gothicum in 1775, and Missale gothicum in $1804 .{ }^{9}$ From the $11^{\text {th }}$ up till the $20^{\text {th }}$ century Toledo was the only place in which the ancient Spanish Church liturgy was continuously celebrated. The reforms, first of Cardinal Cisneros and then of Cardinal Lorenzana, were made in the spirit of the times in which they were introduced, so

${ }^{6}$ They are traditional Mozarabic parishes of Toledo: Parish of St. Justa and Rufina, St. Eulalia, St. Luke, St. Mark, St. Torquatus and St. Sebastian. Apart from the Corpus Christi chapel in the Primate Cathedral of Saint Mary of Toledo, the Mozarabic liturgy is systematically celebrated in two more city parishes (Parish of St. Justa and Rufina and Parish of St. Eulalia).

7 They concerned the so-called Tradition "B," included in the Mozarabic books of the Toledo parishes, which, most probably, originated in Seville. It is quite different from the so-called Tradition "A," which comes from the north of Spain; Cf. J. Pinell, Liturgia hispánica, Barcelona 1998, p. 39-40.

${ }^{8}$ Cf. Á. Fernández Collado, La Catedral de Toledo en el siglo XVI: vida, arte y personas, Toledo 1999, p. 129-130.

9 Cf. F. M. Arocena Solano, Ryt hiszpańsko-mozarabski, „Roczniki LiturgicznoHomiletyczne” 1 (2010), p. 6-7. 
one of their characteristics was obviously "romanisation," which meant introducing elements characteristic for the Roman liturgy celebrated at that time in Toledo. In this way, on the threshold of the Second Vatican Council, the Mozarabic Liturgy celebrated in accordance with Missale and Breviarium gothicum kept its traditional euchology and the basic structure of ordo missae, however, the ritual form and many typically Roman ritual elements made it similar to the Roman liturgy of that time. It needs to be emphasised that, despite its limited range, the Mozarabic Liturgy is a real Liturgy of the Church - living and celebrated every day for many centuries. ${ }^{10}$ Its renewal in the spirit of the Second Vatican Council results directly from its vitality and its influence on the life and identity of the Spanish Church.

From the aforementioned historical conditions of the development of both liturgies we can easily conclude that both the range of the Mozarabic Rite as well as its form and influence on the spirituality of the faithful and their culture that have been taking place for almost a thousand years were much more limited than the same elements of the Ambrosian Rite. It is therefore no surprise that the post-conciliar liturgical renewal in the Ambrosian circles began as early as late nineteen sixties, while the need of reform of the Mozarabic Rite was not recognised till mid-seventies.

\section{Common Elements for the Renewal of Both Rites}

Despite many differences in the history of both non-Roman rites of the Latin Church, the post-conciliar renewal of the Ambrosian and Mozarabic Rites points to the elements that the two Liturgies have in common. Firstly, the renewal itself is based on the deep theological reflexion on the significance of the local Church - the result of both the conciliar Dogmatic Constitution on the Church Lumen gentium and the

${ }^{10}$ Cf. G. Ramis, Pervivencia y actualidad del rito hispano-mozárabe, "Notitiae" 19 (1983), p. 283. 
Decree on the Pastoral Office of Bishops Christus Dominus. It is thanks to the conciliar ecclesiological reflection that liturgy became the space of manifestation for the local Church, and, as a result, ancient and traditional rites were appreciated. ${ }^{11}$ The experience of the Church in the $20^{\text {th }}$ century clearly showed that liturgy can be renewed in the spirit of tradition only when the process has strong ecclesiological foundations. The process of renewal of the Ambrosian and Mozarabic Rites was inspired by and based on the experiences of the reform of the Roman Liturgy, which was simultaneously taking place. What seems to be particularly important for the process itself is the way of interpreting the instructions of the Constitution on Liturgy, methodology of work, the choice of sources and the pastoral aspects of the renewal. ${ }^{12}$

The second element that the post-conciliar processes of renewal of the Ambrosian and Mozarabic Rites have in common is the fact that both of them are based on source texts and historical research, at the same time attempting to preserve all that is unique and original for each of these traditions. Their renewal was possible due to intense historical, patristic and liturgical research on the beginnings and origins of both rites. The conducted historical research revealed the abundance of authentic Ambrosian and Mozarabic traditions, which made it obvious for the Churches in Milan and Toledo that their liturgical identity needed to be rethought in the spirit of the Second Vatican Council. ${ }^{13}$

Another common element of the renewal of the two rites are the great Church pastors, outstanding scholars and Spanish and Italian theologians, who initiated and conducted the process. The renewal of the Ambrosian Rite was initiated, and then supervised for a number of years, by Cardinal Giovanni Colombo, the Archbishop of Milan from 1963 to $1979 .{ }^{14}$ In

${ }^{11}$ Cf. C. Alzati, Ambrosianum mysterium: la chiesa di Milano e la sua tradizione liturgica, Milano 2000, p. 201.

${ }^{12}$ Cf. V. A. Lenti, Liturgical Reform..., op. cit., p. 418.

${ }^{13}$ Cf. A. Ivorra, A 20 años de la reforma del misal hispano-mozárabe, "Studium Legionense" 53 (2011), p. 140-141.

${ }^{14}$ The Archbishop of Milan holds the title of the "Chief of the Ambrosian Rite" (Italian: Capo Rito Ambrosiano). The reform initiated by Cardinal Colombo was continued by 
this period, a group of excellent historians, liturgists and theologians, including Inos Biffi and Giacomo Biffi (who later became a cardinal and the Archbishop of Bologna), worked on the renewal of their own liturgical tradition. ${ }^{15}$ The renewal of the Hispano-Mozarabic rite was started and carried out with great determination by Cardinal Marcelo González Martín, the Archbishop of Toledo and the Primate of Spain from 1971 to 1995. ${ }^{16}$ Among the scholars-specialists, father Jordi Pinell, a Benedictine from the Catalan Abbey of Monserrat, was the one who had the greatest influence on the renewal of the Mozarabic Liturgy, through his historical and liturgical studies, personal involvement and determination. ${ }^{17}$

Despite the common elements, the processes of renewal of the two rites were autonomous, and the choices made at different stages of the reform resulted from the suggestions of the main - Roman - stream of the Church Liturgy renewal after Vaticanum II. Therefore, it seems expedient to present the reform of each of the rites separately.

\section{The Ambrosian Liturgy Renewal and Its Results}

The beginnings of the renewal and the reform of the Ambrosian Liturgy can be found in the activity of the representatives of the Liturgical Movement in the context of the Church of Milan, among whom the one

his successors: Cardinal Carlo Maria Martini and Cardinal Dionigi Tettamanzi, who promulgated the gradually renewed liturgical books.

${ }^{15}$ It needs to be emphasised that the renewal of the Ambrosian Rite would not have been possible without the efforts of Pietro Borella, Angelo Paredi, Enrico Cattaneo, and among younger scholars: Marco Navoni, Claudio Magnoli and Cesare Alzati.

${ }^{16}$ Cf. J. López Martin, El „Missale Hispano-Mozarabicum” del Cardenal González Martín, „Salmaticensis” 39 (1992), p. 273. The Archbishop of Toledo holds the title of the HispanoMozarabic Rite Superior (Spanish: Superior Responsable del Rito Hispano-Mozárabe).

${ }^{17}$ A. Ivorra, $A 20$ años..., op. cit., p. 140. For many years J. Pinell was also a professor of the Pontifical Institute of Sacred Liturgy in Rome; cf. I. Scicolone, Liturgia e poesia: il. Prof. Jordi Pinell i Pons, [in:] Psallendum: miscellanea di studi in onore del prof. Jordi Pinell i Pons, O.S.B., a cura di I. Scicolone, Roma 1992, p. 19-30. 
who has affected the reforms the most is Cardinal Alfredo Ildefonso Schuster, the Archbishop of Milan from 1929 to $1954 .{ }^{18} \mathrm{He}$ was the one who initiated and supported important historical and theological research on the Ambrosian liturgical heritage, as well as successive publishing of the liturgical sources of the Church in Milan. ${ }^{19}$ When the Constitution on the Sacred Liturgy was proclaimed, the scholarly research on the Ambrosian Rite had been developing for many years and questions concerning the traditional rite arose. After the Second Vatican Council the Church in Milan considered resigning from the Ambrosian tradition and accepting in the Milan Church the renewed Roman Rite with some traditional Ambrosian elements preserved. ${ }^{20}$ The discussions among the clergy concerning this issue were quite heated, which resulted in the interest of Pope Paul VI in the matter, partly due to the fact that he himself had been the Archbishop of Milan from 1954 to 1963. During the audience on 11 April 1970 the Pope made it clear that giving up the Ambrosian tradition was unacceptable, and the mission that the Church in Milan was facing was the renewal and the reform of her own liturgy. The Pope's attitude made it possible for Cardinal Colombo to initiate the process of the Ambrosian Rite renewal in the spirit of and in accordance with the norms laid down in the Conciliar Constitution Sacrosanctum Concilium. ${ }^{21}$

The aforementioned doubts and differences of opinions were crucial for the history of the Ambrosian Rite as thanks to them, on the threshold of the renewal, the reformers were not faced with institutional or legal problems, but with theological issues resulting from the awareness of liturgical autonomy of the Church in Milan, which was caused by opening to the conciliar ecclesiology, emphasising the role and significance

${ }^{18}$ At the turn of the $19^{\text {th }}$ and the $20^{\text {th }}$ centuries serious studies on the origins of the Ambrosian Liturgy were conducted first by Antonio Maria Ceriani, and then by Marco Magistretti and Achille Ratti, who later became Pope Pius XI.

${ }^{19}$ Cf. B. Neunheuser, Riforme della liturgia ambrosiana: progetti - iniziative - realizzazioni - speranze, [in:] Studi Ambrosiani in onore di mons. P. Borella, ed. C. Alzati, A. Majo, Milano 1982, p. 177-183.

${ }^{20}$ Cf. C. Alzati, Il Lezionario della Chiesa ambrosiana..., op. cit., p. 81-82.

${ }^{21}$ Cf. C. Alzati, Ambrosianum mysterium..., op. cit., p. 202. 
of local churches. ${ }^{22}$ For more than a thousand years the Ambrosian Rite has been a part of the tradition which shapes the identity of the Church in Milan and the position of the St. Ambrose Diocese in the spiritual and theological image of the Catholic Church. Its renewal, similarly to the renewal of the Roman Rite, was necessary and, at the same time, natural and could only be undertaken by the whole local church guided by their own pastor. ${ }^{23}$ In the end, the reform and the renewal of the Ambrosian Liturgy was supposed to be based on three foundations. The first one was supposed to be the Ambrosian tradition of the local church, the second one - theological and pastoral criteria of the Second Vatican Council documents, and the third one - the changing social context of the contemporary world. ${ }^{24}$ In this way the 'preservation and renewal of the Ambrosian Liturgy' that Cardinal Colombo mentioned in his pastoral letter to the clergy and the faithful of his Diocese on 21 November 1970 became possible. ${ }^{25}$

The model for the renewal of the Ambrosian Liturgy was supposed to be the Roman Missal of Paul VI, published in 1970, in which the whole conciliar attempt to make liturgy the source of Christian life and strengthen the real participation of the faithful in the celebrated mysteries was reflected. In the attempt of taking advantage of the experiences gained during the renewal of the Roman Missal, in the aforementioned pastoral letter Cardinal Colombo set up the Committee for the Reform and Development of the Ambrosian Rite, which was responsible for preparing projects concerning reforms of particular elements of the Ambrosian Rite in order to present them for assessment in front of proper liturgical

${ }^{22}$ More on the doubts caused by the Ambrosian Rite reform on the threshold of the conciliar renewal, cf. A. M. Triacca, Riforma liturgica, [in:] Dizionario di liturgia ambrosiana, a cura di M. Navoni, Milano 1996, p. 454-455.

${ }^{23}$ Cf. F. Dell'Oro, Il nuovo Messale della Chiesa ambrosiana, "Rivista Liturgica" 64 (1977), p. 538-539.

${ }^{24}$ Cf. A. M. Triacca, La Liturgia ambrosiana..., op. cit., p. 107.

${ }^{25}$ Cf. I. Biffi, Il nuovo messale della Chiesa ambrosiana: spirito e principi della sua riforma, "Ambrosius" 52 (1976), p. 81-82. 
bodies of the St. Ambrose diocese. ${ }^{26}$ It soon turned out that this method of work was not effective enough in the Church of Milan and, after one year of activity, the Committee was dissolved. ${ }^{27}$ It was the turning point of the reform and the works continued under the supervision of Inos Biffi, together with a group of specialists on the Ambrosian Liturgy. ${ }^{28}$ Thanks to their involvement in 1976 the renewed Ambrosian Missal was published. ${ }^{29}$ Five years later its Latin version was released and in 1986 and 1990 - its two completed editions were published. ${ }^{30}$

The renewal of the Missal is strongly connected with the renewal of the Ambrosian Calendar. In 1970 in Milan the new Roman Calendar, published a year before in accordance with the instructions of the Second Vatican Council and, to some extent, substituting the previous Calendar of Lombardy, was officially adopted. In this way, without much hesitation, crucial changes concerning the typical Ambrosian elements were implemented. Two of them were particularly important. Firstly, the characteristic six-week Advent in Milan was substituted with the Roman four weeks, and the Roman concept of ordinary time, previously uncustomary for the Ambrosian tradition, was introduced per annum. It was only after the intervention of Paul VI that Milan returned to its traditional six-week

${ }^{26}$ Cf. F. Dell'Oro, Il nuovo Messale..., op. cit., p. 540-543.

${ }^{27}$ Cf. ibidem, p. 545-546.

${ }^{28}$ Cf. B. Neunheuser, Riforme della liturgia ambrosiana..., op. cit., p. 184. At this stage of the reform Inos Biffi cooperated closely with Enrico Galbiatti, as well as Franco Brovelli and Gianfranco Ravasi.

${ }^{29}$ Messale Ambrosiano secondo il rito della santa Chiesa di Milano, riformato a norma dei decreti del Concilio Vaticano II, promulgato dal Signor Cardinale Giovanni Colombo, Arcivescovo di Milano, vol. 1-2, Milan 1976. The Missal starts with the pastoral letter of Cardinal Colombo, decrees of the Congregation for Divine Worship and the Discipline of the Sacraments signed by its Prefect, Cardinal James Knox, Norms and Rules of the Ambrosian Rite Use (Principi e norme pr l'uso del Messale Ambrosiano) consisting of 354 points and The General Norms of the Liturgical Year and Calendar (Norme generali per l'ordinamento dell'anno liturgico e del calendario).

${ }^{30}$ More on the completed editions of the Ambrosian Missal, cf. M. Navoni, La seconda ristampa del Messale Ambrosiano, “Ambrosius” 67 (1991), p. 152-177. 
period of celebrating the Ambrosian Advent, but the issue of the typical for the Milan tradition period de Tempore needed to wait for the next thirty years to be addressed. ${ }^{31}$

The issue of a lectionary concordant with the tradition of the Church in Milan is an important aspect of the process of the renewal and reform of the Ambrosian Rite. The first lectionary, so far ad experimentum, was published together with the Missal in $1976 .{ }^{32}$ It contained only the structure of the Lent, Octave of Easter and the Easter Time and some traditional elements of the celebrations connected with the mystery of the Lord's Nativity. In the remaining liturgical times the Roman Lectionary used in other Italian dioceses was reached for. ${ }^{33}$ For the fully renewed Ambrosian ordo lectionum Milan had to wait for more than thirty years. After decades of intensive works and studies, ${ }^{34}$ on Maundy Thursday 2008 Cardinal Dionigi Tettamanzi promulgated the final form of the Ambrosian Lectionary, which contained all times of the Liturgical Year and fully preserved many elements traditional for the Liturgy of the Word characteristic of the Church in Milan. ${ }^{35}$ At this stage the reform of the Ambrosian Rite was complete. It had come over the temporary and partial character of its lectionary from 1976, which in 2008 gave the church communities celebrating the Ambrosian Rite a complete and characteristic system of

${ }^{31}$ Cf. N. Valli, "Redemptionis enim nostrae magna mysteria celebramus": il ciclo de Tempore nella liturgia ambrosiana, "Rivista Liturgica" 96 (2009), p. 508.

${ }^{32}$ Lezionario Ambrosiano edito per ordine del Sig. Cardinale Giovanni Colombo Arcivescovo di Milano: ad experimentum, Milano 1976.

${ }^{33}$ Cf. C. Alzati, Il Lezionario della Chiesa ambrosiana..., op. cit., p. 83-84.

${ }^{34}$ Cf. C. Magnoli, Piccola guida al nuovo Lezionario ambrosiano, Milano 2008, p. 7-10.

${ }^{35}$ Lezionario Ambrosiano secondo il rito della santa Chiesa di Milano, riformato a norma dei decreti del Concilio Vaticano II promulgato dal Signor Cardinale Dionigi Tettamanzi, Arcivescovo di Milano e Capo Rito, Milano 2008. The pastoral letter of Cardinal Tettamanzi, the decree of the Congregation for Divine Worship and the Discipline of the Sacraments signed by its Prefect Francis Arinze, as well as the Introduction (Messale Ambrosiano, Lezionario, Premesse) consisting of 231 points, were also published in the first volume. 
scripture readings for the whole Liturgical Year. ${ }^{36}$ Although publishing the Ambrosian Lectionary provoked numerous discussions among specialists, ${ }^{37}$ required openness from particular communities, as well as implementing and accepting quite serious changes in the content and structure of the Liturgy of the Word, it can be said that the new lectionary was universally well received in all the places where the Ambrosian Rite is celebrated.

The next element of the Ambrosian Liturgy reform after the Second Vatican Council is the renewal of the Liturgy of the Hours according to the Rite of the Holy Church in Milan. Throughout the centuries, the Ambrosian Liturgy preserved rich traditions concerning officium divinum. However, after Vaticanum II, parallelly to the reform of the Roman Liturgy, the Ambrosian clergy, in a way spontaneously, turned to the Roman Liturgia horarum, considering it to be in more agreement with contemporary spirituality and the character of pastoral work. Roman Officium divinum in connection with the Ambrosian Missal and Calendar formed a kind of anomaly, which disturbed the liturgical unity of the Church in Milan. ${ }^{38}$ The renewal of the Liturgy of the Hours became a natural consequence of the general process of the renewal of the Ambrosian Rite, which had been taking place since 1970. The renewal of the Ambrosian officium was faced with some difficulties, comparable with the renewal of the missal. Initially, of Cardinal Colombo's will and following the advice of Paul VI, from 1973 the issue of the breviary reform was entrusted to Aimé Georges Martimort, whose project turned out to be similar to the renewed Roman Liturgy of the Hours. For fear of the threat to the Ambrosian identity of the office, the works of Martimort's Committee were suspended in 1977

${ }^{36}$ Cf. C. Magnoli, Il Lezionario ambrosiano per i tempi liturgici, "Rivista Liturgica" 96 (2009), p. 488.

${ }^{37}$ Cardinal Giacomo Biffi was, apart from other scholars, one of the critics of the new Lectionary. Cesare Alzati, the main architect of the renewal of the Ambrosian liturgy of the word, entered into a dispute with the Cardinal. Traces of their opinion exchange can be found in press publications from 2010; cf. http://chiesa.espresso.repubblica.it/ articolo/1342120 (17 Jan 2013).

${ }^{38}$ Cf. A. M. Triacca, Ambrosiana, liturgia, [in:] Liturgia, a cura di D. Sartore, A. M. Triacca, C. Cibien, Cinisello Balsamo (Milano) 2001, p. 29. 
by the then secretary of the Ambrosian Rite Congregation and auxiliary bishop of Milan Giacomo Biff. ${ }^{39} \mathrm{He}$ was the one who continued the works on completing the reform of the Ambrosian officium divinum since 1980. The first outcome of the reform was completing the works on the office of lauds, minor hours, vespers according to the psalter divided into four weeks, as well as the compline and some offices connected with the liturgical year, published in 1981 under the title referring to the Milan tradition - Diurna laus. Between 1983 and 1984 Cardinal Carlo Maria Martini promulgated the renewed five-volume Liturgy of the Hours according to the Holy Ambrosian Church Rite. ${ }^{40}$ The book of the Liturgy of the Hours perfectly inscribes in the tradition of the Church in Milan, at the same time bearing great similarity to the reformed Roman officium divinum earlier introduced in the universal Church. The wide range of texts of the Ambrosian origin, the return to the foundations of the prayer characteristic for the Milan Church, and wide celebratory possibilities make the renewed Liturgy of the Hours a ripe fruit of reflection on the liturgical identity of the local church. The clergy and the communities of the Ambrosian Rite have been using it for almost thirty years with no need of reaching for the Roman office.

During the process of the Ambrosian Rite renewal other liturgical books were also prepared, and were gradually published and introduced for use during celebrations. Among them we can find Funeral rituals (1977 and 2002) and First Communion and The Worship of the Eucharist Outside Mass (1984), as well as semi-official books containing the traditional Ambrosian chant. ${ }^{41}$ Till now some of the liturgical books of the Church in Milan have not been renewed, so we can say that the post-conciliar liturgical reform is still in progress. It needs to be kept in mind that the publication of liturgical books is not only accompanied by extensive re-

${ }^{39}$ Cf. C. Alzati, Ambrosianum mysterium..., op. cit., Milano 2000, p. 205.

${ }^{40}$ Liturgia delle ore secondo il rito della santa Chiesa ambrosiana, riformata a norma dei decreti del Concilio Vaticano II e promulgata dal Cardinale Carlo Maria Martini Arcivescovo di Milano, t. 1-5, Milano 1983-1984.

${ }^{41}$ Cf. A. M. Triacca, Ambrosiana, liturgia..., op. cit., p. 35-36. 
search, but also by the liturgical formation of the faithful, which can be seen in numerous works on the renewed Ambrosian Liturgy. ${ }^{42}$

\section{The Hispano-Mozarabic Liturgy Renewal and Its Results}

The renewal process of the ancient Mozarabic Liturgy needs to be analysed in the context of the renewal of the Roman and the Ambrosian Rites, since it began in the mid-seventies, when the renewed Roman and Ambrosian missals were already being used in liturgy. The Church reform after the Second Vatican Council strongly influenced the way of perceiving liturgy as the essence of the ecclesiastical identity. The church in Spain was strongly influenced by this change of attitude, as it had in its possession the incredibly valuable Mozarabic Liturgy, which for centuries had been seen as venerable antiquity and archaeological relic rather than the living liturgy that has the power to influence the lives and the faith of Christian communities.

Presenting the process of the Mozarabic Liturgy renewal different authors tend to present it in a broader historical context, mentioning its various stages: pre-history, history and contemporary times. ${ }^{43}$ The pre- historical stage of the Mozarabic Liturgy renewal is reflected in the $20^{\text {th }}$ century academic and pastoral interest in the Mozarabic Rite in the whole Spain, which in many places - after receiving the approval of the Congregation of Rites - initiated the celebration of the liturgy in accordance with the existing liturgical books. ${ }^{44}$ The climax of this process was

\footnotetext{
${ }^{42}$ Sussidi Liturgici collection of the Publishing House Àncora in Milan can serve as an example of a publication providing introduction to the renewed Ambrosian liturgy of the word.

${ }^{43}$ Cf. G. Ramis, La reforma del rito hispano-mozárabe en el contexto del movimiento litúrgico, [in:] El movimiento litúrgico y la reforma litúrgica, Barcelona 2009, p. 110.

${ }^{44}$ Cf. M. Ramos, Revisión "ex integro" de la liturgia hispano-mozárabe, "Ephemerides Liturgicae" 99 (1985), p. 508-509.
} 
the celebration of the Holy Mass in the Mozarabic Rite in the conciliar auditorium, in front of all the Fathers of Vaticanum II, on 15 October 1963. ${ }^{45}$ Two events of academic character had a strong impact on the decision to renew the Mozarabic Rite. The first one was the I International Congress on Mozarabs, which was held in Toledo in $1975^{46}$; the second one was funding and the activity of the St. Eugene Institute of Visigoth and Mozarabic Studies. ${ }^{47}$ The research on the origins of the Mozarabic Liturgy, conducted in the atmosphere of the conciliar renewal, became the next step towards the reform of the Mozarabic Rite. On 12 July 1982 Cardinal González Martín set up the Committee for the Mozarabic Rite Reform, the aim of which was the revision and renewal of the liturgical books used in the Mozarabic Liturgy celebration. ${ }^{48}$ The President of the Committee was the Cardinal himself, its works were supervised by Jordi Pinell, and Gabriel Ramis acted as its secretary. ${ }^{49}$ The main goal of the Committee was preparing a new edition of the missal, as well as the renewed ritual of baptism, confirmation, marriage and funeral. The renewal of order rituals was not taken into consideration, as in the current

${ }^{45}$ Cf. F. Fernández Serrano, Documentos del rito mozárabe en el entoro del Concilio Vaticano II, [in:] Liturgia y musica mozárabes. Ponencias y Comunicaciones presentadas al I Congreso Internacional de Estudios Mozárabe. Toledo 1975, Toledo 1978, p. 228.

${ }^{46}$ During the Congress father Pinell gave his famous lecture on the need of the Mozarabic Rite renewal; cf. J. Pinell, El problema de las dos tradiciones el antiguo rito hispánico. Valoración documental de la tradición, en vistas de una eventual revisión del Ordinario del la Misa mozárabe, [in:] Liturgia y musica mozárabes..., op. cit., p. 3-44.

${ }^{47}$ Instituto de Estudios Visigótico-Mozárabes de S. Eugenio established on 9 June 1977, is thought to be the result of the 1975 Congress; cf. G. Ramis, La reforma del rito hispano-mozárabe en el contexto..., op. cit., p. 114.

${ }^{48}$ Cf. A. Ivorra, $A 20$ años..., op. cit., p. 139.

${ }^{49}$ Cf. G. Ramis, La reforma del rito hispano-mozárabe, [in:] La reforma litúrgica: una mirada hacia el futuro, Bilbao 2001, p. 158-160. During the eleven years of its activity, the Committee had the following members: José Aldazábal, Antonio Cabrera, Jaime Colomina, Jordi Gibert, Balbino Gómez-Chacón, Andrés Pardo, Jordi Pinell, Gabriel Ramis, Manuel Ramos, Cleofé Sánchez, Jaime Sancho, Lamberto de Echevarría, Manuel-Francisco Sánchez, Juan-Miguel Ferrer, Juan-Javier Flores, Javier Altés and Juan María Canals. 
situation of the Spanish Church it would be difficult to imagine deacon or presbyter ordination in the Mozarabic Rite, not to mention the ordination of bishops. Similarly, the ritual of the anointing of the sick was not prepared either, since no such need was recognised. Nor was the ritual of penance, due to the theological and historical problems associated with it. During the works on the reform of the Mozarabic Rite the process of the breviary renewal was not initiated. ${ }^{50}$

The Committee for the Mozarabic Rite Reform worked intensively for a few years in communication with the Vatican Congregation for Divine Worship, and, as a result of its efforts, the renewed liturgical books of the Mozarabic tradition were published. In 1991 the first volume of the renewed Missale Hispano-Mozarabicum was released. ${ }^{51}$ In the same year the first volume of the renewed Lectionary appeared, under the traditional for the Mozarabic Liturgy title Liber Commicus. Both these books contained the euchology and readings of the de Tempore cycle. ${ }^{52}$ In 1994 the second volume of Missale Hispano-Mozarabicum was published, and in 1995 - the second volume of Liber Commicus. ${ }^{53}$ In both these books a much greater emphasis was put on the use of liturgical sources than in case of the Ambrosian Liturgy. That is why both in the structure of celebration and in the texts one can notice incredible variety, characteristic for the Mozarabic tradition almost from the very beginning. ${ }^{54}$

${ }^{50}$ Cf. G. Ramis, La reforma del rito hispano-mozárabe en el contexto..., op. cit., p. 118-119.

${ }^{51}$ Missale Hispano-Mozarabicum, vol. 1, ed. Conferencia Episcopal Española - Arzobispado de Toledo 1991. The Missal was preceded by the introduction of Cardinal González Martín and the decrees of the then President of the Spanish Episcopal Conference Cardinal Ángel Suquía Goicoechea and the Prefect of the Congregation for Divine Worship and the Discipline of the Sacraments Cardinal Eduard Martínez Somalo. The book included Praenotanda consisting of 170 points.

${ }^{52}$ Liber Commicus, vol. 1, ed. Conferencia Episcopal Española - Arzobispado de Toledo 1991.

${ }^{53}$ Missale Hispano-Mozarabicum, vol. 2, ed. Conferencia Episcopal Española - Arzobispado de Toledo 1994; Liber Commicus, vol. 2, ed. Conferencia Episcopal Española - Arzobispado de Toledo 1995.

${ }^{54}$ Cf. V. A. Lenti, Liturgical Reform..., op. cit., p. 426. 
Since the missal and the lectionary are the only liturgical books of the Mozarabic tradition renewed after Vaticanum II, many of the aims of the reform have not been achieved. The rites of the Christian initiation and marriage were prepared by the Committee, but were never presented in front of the Spanish Episcopal Conference, and, as a result, could not have been approved by the Holy See. The reform of the funeral rite has never moved beyond the project stage. ${ }^{55}$

This phase of the reform was crowned with the celebration of the Eucharist in accordance with the new Missale Hispano-Mozarabicum, which was presided by Pope John Paul II on the 28 May 1992 in St. Peter's Basilica in Rome. ${ }^{56}$ Despite the fact that the missal and the lectionary of the Mozarabic Rite were published, the reform itself was not complete. Since 1993 further works connected with the renewal and appropriate celebration of the Rite have been supervised by the Committee for the Continuation of the Mozarabic Rite Reform. ${ }^{57}$

\section{The Ambrosian and the Mozarabic Rite Today - Future Perspectives}

The Ambrosian Liturgy is currently celebrated in the whole Archdiocese of Milan and in more than one hundred parishes from neighbouring dioceses. It is therefore a living liturgy, forming great cultural and spiritual

${ }^{55}$ Cf. G. Ramis, La reforma del rito hispano-mozárabe en el contexto..., op. cit., p. 118.

${ }^{56}$ Cf. J. Colomina Torner, 1992: Toledo mozárabe en Roma, „Toletum” 28 (1992), p. $153-154$.

${ }^{57}$ The so-called Comisión de seguimiento, the members of which are chosen Mozarabic priests from Toledo. It fulfils the instructions of Praenotanda 158-170 (El Misal HispanoMozárabe. Prenotandos, Barcelona 2002, p. 59-62) concerning the norms connected with the practical use of the renewed missal, both in Spain and abroad; cf. G. Ramis, La reforma del rito hispano-mozárabe en el contexto..., op. cit., p. 119. 
heritage of the Church in Milan. ${ }^{58}$ Its reform and renewal were necessary, so that it could express ambrosianum mysterium at the same time responding to contemporary conditions and needs. The analysis of the whole process, especially of its turbulent beginning, convinces us that the Ambrosian Rite is deeply rooted in the devotion and spirituality of the faithful.

The aim of the renewal of the Mozarabic Liturgy after Vaticanum II was not an attempt to restore the rite in the whole Spain. It never seemed justified, or even possible. Specific liturgical tradition is an important element of the Christian patrimonium of Spain, therefore, the reflexion on its origins and its development became a way of discovering the richness of tradition maintained by the Church. Today the Hispano-Mozarabic Liturgy is celebrated every day only in Toledo and at regular intervals in Madrid and Salamanca. ${ }^{59}$ Occasional celebrations are organised in other parts of Spain. The post-conciliar reform drew people's attention to the existence of the almost forgotten rite of the Spanish Church and to its pastoral influence on the faithful living in the $20^{\text {th }}$ and the $21^{\text {st }}$ century.

The outcome of the process is much more than publishing the liturgical books - it is also the extension of the local Church theology. Despite the fact that there is still much work connected with the renewal of both rites, the liturgical identity of the faithful formed in the liturgical Ambrosian and Hispano-Mozarabic spirituality grew stronger thanks to the Second Vatican Council and the reform. The liturgical heritage of Milan and Toledo cannot be seen merely as a treasure to be preserved and protected. It must also be appreciated as a clear expression of spirituality and ecclesiastical awareness.

Looking at the process of renewal of both liturgies from today's perspective, it seems that it needs to develop in two main directions. The first one is the continuation of academic research on sources, the second one

${ }^{58}$ Cf. M. Mauri, La geografia del rito ambrosiano, "Rivista Liturgica” 96 (2009), p. 657. There are a few million faithful living in the Ambrosian Rite area.

${ }^{59}$ Cf. A. Ivorra, A 20 años..., op. cit., p. 161. Currently about one thousand families belong to the two Mozarabic parishes of Toledo. Half of them live in Toledo, about two hundred families - in Madrid, and others - in different parts of Spain; cf. R. Gómez-Ruiz, Mozarabs, Hispanics, and the Cross, Maryknoll NY 2007, p. 6-7. 
- the formation of the faithful to participation in the liturgy and to its better understanding. The second direction of development seems to be particularly important, as, in a way, it makes the wishes of the conciliar Fathers come true, since from the very beginning the main aim of the reform was supposed to be the "new vigor to meet the circumstances and needs of modern times” (SC 4).

\section{Summary}

\section{The Renewal of the Ambrosian and the Hispano-}

\section{Mozarabic Liturgy after the Second Vatican Council}

The reform of the Catholic liturgy following the Second Vatican Council was primarily concerned with the Roman Rite, but two other liturgical traditions of the Western Church - the Ambrosian Rite in Milan and the Mozarabic Rite in Toledo - also required renewal. The revision of the Roman liturgical books was followed by a similar revision of the Ambrosian Missal, Lectionary, Liturgy of the Hours and the rituals of some sacraments. The renewed Mozarabic missal and lectionary (Liber Commicus) were published between 1991 and 1995. The reform of the Ambrosian and Mozarabic Rites in the past forty years has shown the liturgy as one of the most important components of the identity of the local Church.

\section{Keywords}

Ambrosian Liturgy, Ambrosian Rite, Mozarabic Liturgy, Mozarabic Rite, liturgical reform, liturgical renewal, Second Vatican Council 


\section{Streszczenie}

\section{Odnowa liturgii ambrozjańskiej i hiszpańsko- mozarabskiej po Soborze Watykańskim II}

Reforma liturgii katolickiej po Soborze Watykańskim II odnosiła się przede wszystkim do obrządku rzymskiego, ale odnowy wymagały także dwie pozostałe tradycje liturgiczne Kościoła zachodniego: obrządek ambrozjański w Mediolanie i obrządek mozarabski w Toledo. Odnowa rzymskich ksiąg liturgicznych stała się wzorem dla reformy ksiąg ambrozjańskich: mszału, lekcjonarza, liturgii godzin oraz rytuałów niektórych sakramentów. Odnowione mozarabskie księgi liturgiczne: mszał i lekcjonarz (Liber Commicus) zostały natomiast opublikowane między rokiem 1991 a 1995. Posoborowa reforma rytu ambrozjańskiego i mozarabskiego dokonana w ciągu ostatnich czterdziestu lat jest świadectwem tego, że liturgia należy do najważniejszych fundamentów tożsamości Kościoła lokalnego.

\section{Słowa kluczowe}

Liturgia ambrozjańska, ryt ambrozjański, liturgia mozarabska, ryt mozarabski, reforma liturgiczna, odnowa liturgiczna, Sobór Watykański II 